Права людини в Україні та у зарубіжних країнах:

проблеми теорії та нормативно-правової регламентації

DOI https://doi.org/10.36059/978-966-397-210-7/283-305

\author{
Любченко М. I., \\ кандидат юридичних наук, \\ доцент кафедри теоретико-правових дисциплін \\ Полтавського юридичного інституту \\ Національного юридичного університету \\ імені Ярослава Мудрого, \\ м. Полтава
}

Буряковська К. О.,

кандидат юридичних наук,

асистент кафедри теорії і філософії права

Національного юридичного університету

імені Ярослава Мудрого,

м. Харків

\title{
СУЧАСНИЙ МІЖНАРОДНИЙ ПРАВОПОРЯДОК У КОНТЕКСТІ СТ. 28 ЗАГАЛЬНОЇ ДЕКЛАРАЦІЇ ПРАВ ЛЮДИНИ
}

Анотація. У підрозділі розглянуто проблему справедливого міжнародного ладу в контексті проголошеного у ст. 28 Загальної декларації прав людини права кожного на такий міжнародний порядок, який зробить можливим повну реалізацію прав людини. Автор з'ясовує нормативні засади побудови міжнародних відносин та співробітництва після заснування Організації Об'єднаних Націй та прийняття Загальної декларації прав людини. Також досліджуються основні виклики, які стоять перед міжнародним правопорядком сьогодні, особливо пов'язані із правами людини. Розглядається теорія глобальної справедливості як така, що адекватна тим запитам на справедливий світ, які проголошені в низці документів під егідою ООН і не тільки. Проводиться аналіз можливості застосування ідеї справедливості, що зазвичай використовується в контексті національного правопорядку, до міжнародних відносин у широкому сенсі. З'ясовується, що у глобальному вимірі на перший 
Права людини в Україні та у зарубіжних країнах:

проблеми теорії та нормативно-правової регламентації

план виходить дистрибутивний аспект справедливості. Досліджено концепцію сталого розвитку та їі співвідношення з ідеєю сталого розвитку.

\section{Вступ}

Загальну декларацію прав людини, прийняту Генеральною асамблеєю ООН 10 грудня 1948 року, тобто більш ніж 70 років тому, беззастережно можна назвати найголовнішим документом, який вплинув на долю людства та назавжди змінив світовий порядок. Цей акт глобального рівня засвідчив те, що посягання на людську гідність вже не може розглядатись як допустиме взагалі, i на порядку денному стоїть «створення такого світу, в якому люди будуть мати свободу слова і переконань і будуть вільні від страху і нужди» (Преамбула Загальної декларації прав людини). Декларація стала вдалим компромісом різних інтересів політичних сил, які одержали перемогу над фашистськими державами, і у 1948 році цей компроміс був вдало «підхоплений» та зафіксований, адже, як справедливо відзначають у літературі, що така згода і згуртованість навколо ідеї прав людини за часів «холодної війни» уже б була неможлива, що було продемонстровано під час прийняття наступних конвенцій $\mathrm{OOH}$ та інших угод про права людини [10]. Проте це не спинило того правозахисного розвитку, поштовхом та натхненням для якого стала Декларація, попри те, що вона не містить жодних зобов'язань для держав [10]. Найбільшою цінністю Декларації $\epsilon$ те, що вона перетворила ідею (наш курсив) прав людини у реальність - права людини стали тим нормативним мірилом, яке претендує на загальну всесвітню значущість і яке вже не можна ігнорувати [10].

Схоже, це та цінність, яку важко оцінити повною мірою, «справедливість, і свобода, коли вони наявні, стають подібними повітрю», «свідомість не фіксує справедливість», коли вона виражає досягнуту для даного історичного періоду гармонійність, оптимальність людських відносин [16]. 


\section{1. Сучасний міжнародний порядок та ідея прав людини}

Загальна декларація прав людини являє собою каталог прав людини, які можна згрупувати на фізичні, особистісні, культурні, економічні, політичні - залежно від потреб та інтересів людини, а також на колективні, індивідуальні та колективно-індивідуальні - залежно від носї̈в потреб та можливостей реалізації [15, с.35]. Привертають увагу, а точніше ставлять питання про своє місце у структурі та ідеї Декларації, три останні її статті - 28, 29 і 30, адже за своїм змістом вони проголошують загальні умови здійснення прав, передбачених основним текстом Декларації та принципів тлумачення документа, і на перший погляд не проголошують змістовних прав $[15$, с.72]. Як відомо, структура прийнятої Декларації була розроблена французьким правником Рене Кассеном, який порівнював Декларацію з грецьким храмом із фундаментом, східцями, колонами і фронтоном: колони групи прав людини, фундамент - 1 і 2 статті Декларації, сім абзаців Преамбули - сходинки до самої Декларації; останні ж три статті являють собою фронт храму [31, с.100]. С. Рабінович звертає увагу на те, що розміщення статей 28-30 Декларації наприкінці її тексту зумовлене не їх малозначністю, як може здатись, а «загальною логікою «вертикальної» архітектоніки Декларації, організацією розгортання смислів від преамбули і до завершення документа, яке постає радше його вершиною, аніж кінцем» $[15$, c. 72$]$.

Стаття 28 Загальної декларації прав людини проголошує: кожна людина має право на соціальний i міжнародний порядок, при якому права i свободи, викладені в цій Декларації, можуть бути повністю здійснені. В англомовній, оригінальній версії текст цієї статті звучить так: «Everyone is entitled to a social and international order in which the rights and freedoms set forth in this Declaration can be fully realized». "To entitle» перекладається як надавати право, уповноважувати [3]. Чи $\epsilon$ такий переклад статті Декларації українською еквівалентним та чи враховує усі нюанси? Як стає 
Права людини в Україні та у зарубіжних країнах:

проблеми теорії та нормативно-правової регламентації

зрозуміло із історії створення Декларації, на етапі розробки ії авторами було виконано стилістичну заміну «right to» на «entitled to», щоб уникнути тавтології [25, с. 8]. У літературі підкреслюється, що виникає у ст. 28 проголошене sui generis суб'єктивне «мета-право» прав людини: їі право на такий соціальний і міжнародний порядок, у якому можуть бути повністю здійснені викладені в Декларації права і свободи [15, с. 72].

Томас Погге, обгрунтовуючи права людини як моральні вимоги до глобальних інституцій, вважає, що моральне прочитання ст. 28 Декларації звучить так: «Системи інституцій, включаючи глобальну, підлягають переоцінці та реформуванню з урахуванням їхнього відносного внеску в реалізацію прав людини». Т. Погґе звертає увагу на те, що положення ст. 28 не указують на те, яким саме має бути соціальний порядок у наших державах та якими мають бути глобальні інституції, але визначальним критерієм організації цих порядків він вважає те, чи «їх можна реконструювати» відповідно до мети повноцінної реалізації прав людини.

у філософсько-правовій літературі досить багато привернуто уваги питанню справедливого влаштування світу. До, прикладу, П. Коллер виділяє три моделі міжнародного устрою та намагається проаналізувати, як реалізується в них справедливість та права людини:

1) модель розділених самодостатніх окремих суспільств, які мають ресурси і між собою тісно не взаємодіють; тут люди максимум можуть розраховувати на отримання політичного притулку в інших, ніж їх громадянство, державах; при цьому недоступними буде свобода пересування світом та право бідних народів отримати допомогу від багатих;

2) модель усеохоплюючого світового порядку, тобто світ, де нації вплітаються у глобальну кооперацію, держави виконують функції адміністративних єдностей. Тут права людини мають глобальний зобов'язуючий характер, але для цього потрібен відповідний глобальний устрій, де 
будуть забезпечені ліберальні свободи, громадянські, політичні та соціальні права. При цьому національні держави перестають існувати як відносно самостійні політичні спільноти і підпорядковуються наддержавному органу влади з достатніми законодавчими та примусовими повноваженням. Такий світ нівелює різноманіття форм суспільного життя;

3) модель взаємозалежних національних суспільств. Вона $\epsilon$ моделлю всеохоплюючого світового суспільства, але при цьому враховує умови різноманіття відносно самостійних політичних спільнот. Абсолютними та глобальними тут $є$ обов'язки непосягання, тобто негативні обов'язки, а обов'язки позитивних дій покладаються власне на громадян та державні інституції кожного окремого суспільства. Інтернаціоналізація прав людини відбувається у трьох напрямках: 1) дотримання прав людини в усіх державах світу, що вимагає відповідних форм міжнародної кооперації та транснаціональних інституцій, які б покладали на держави зобов'язання дотримуватись прав людини, а також існування міжнародно-правових механізмів притягнення держав до відповідальності. П. Коллер вважає, що міждержавні санкції у сучасному вигляді не обіцяють бути дієвими, адже в більшості випадків такі санкції не досягають своєї мети, посилюють взаємне протистояння, ізолюють громадян держави від зовнішнього світу та $\epsilon$ ризик того, що вони можуть завершитись потужним конфліктом. Застосування та продовження санкцій, як вважає П. Коллер, повинне засновуватись на принципі обачності; 2) запровадження свободи пересування світом для всіх людей, що означає право кожної людини вирушати у будь-яку країну за своїм вибором і там залишатись у відповідності до тих правил, які встановлені державою; 3) справедливий розподіл витрат та здобутків у межах міжнародної кооперації та користуванні природними ресурсами. Існує чимало держав, де люди не мають засобів для гідного життя, що вимагає кардинальної перебудови наявної світової системи, 
справедливого перерозподілу природніх ресурсів, а також перебудови держави - в напрямку підвищення освітніх послуг та посилення доступу людей до інформації, підвищення рівня медичних послуг, скорочення народжуваності. П. Коллер вважає, що наявні механізми відшкодування збитків, завданих несправедливими рішеннями, не можуть вирішити повною мірою ситуацію [9, с. 100-104].

Питання про облаштування післявоєнного світового порядку за новими правилами залишаються актуальними увесь час протягом 70 років. Варто почати 3 того, що загальноприйнятим $\epsilon$ розуміння того, що досягнення тих цілей, які продиктовані Загальною декларацією прав людини, $€$ можливим лише за рахунок міжнародної кооперації, яка заснована на волі та усвідомленості усіх держав. Про це наголошується в самій Декларації (п. 6 Преамбули), де вказується, що справа захисту прав людини відтепер стає предметом співробітництва між державами. Раніше, у п. 3 ст. 1 Статуту Організації Об'єднаних Націй 1945 року, було вказано, що завданням цієї глобальної структури $\epsilon$, зокрема, здійснення міжнародного співробітництва «у сфері розв'язання міжнародних проблем економічного, соціального, культурного та гуманітарного характеру й у заохоченні та розвитку поваги до прав людини й основних свобод для всіх, без розрізнення раси, статі, мови та релігії». Відданість ідеї міжнародної кооперації була відтворена далі у багатьох інших документах найвищого світового рівня, якими держави світу виражали свою відданість цьому принципу та поглиблювали його зміст. Через майже півстоліття у 1993 році 171 державою світу було прийнято Віденську Декларацію та Програму дій, яка стала кульмінацією Всесвітньої конференції з прав людини, де заохочення і розвиток поваги до прав людини і основних свобод для «всіх i повагу принципу рівноправності i самовизначення народів світу, демократії, справедливості, рівності, законності, плюралізмі, розвитку, кращих умов 
життя і солідарності» було основою бажаного та омріяного міжнародного порядку [1]. Неможливо у цьому контексті не відзначити Декларацію про принципи міжнародного права, що стосуються дружніх відносин і співробітництва між державами відповідно до Статуту ООН, яка разом і 3 положеннями Гельсінського заключного акту Наради 3 безпеки і співробітництва в Європі 1975 р. сформували, як зазначає О. Задорожній, «десять заповідей міжнародного права», ключових для цієї системи, без яких саме ії існування неможливе». Професор О. Задорожній наголошує на тому, що сучасний світовий порядок, «заснований на співпраці держав в умовах миру та безпеки може зберігатися лише за умови загального визнання та поваги до цих принципів» [7]. Зокрема, йдеться про принципи, згідно з якими держави вирішують свої міжнародні спори мирними засобами таким чином, щоб не ставити під загрозу міжнародний мир і безпеку та справедливість, й принцип незастосування сили та погрози нею.

Г. Христова підкреслює, що заснування ООН у 1945 році, а також наступні процеси деколонізації призвели до перегляду доктрин класичного міжнародного права та конституціоналізму - доктрини державного суверенітету $[17$, c. 57]. Відповідно до цієї доктрини жодна держава не може бути пов'язана жодною нормою, якщо вона не надавала згоди на таку норму, тому лише два джерела міжнародного права могли застосовуватись до держави: міжнародні договори та міжнародні звичаї (tacitus consensus). Це означало, як слушно відзначає О. Київець, що міжнародні економічні та політичні відносини, які почали у середині XX ст. розвиватись небаченими до тих пір темпами, ризикували не засновуватись на природних правах людини. Досвід другої світової війни та рішення Нюрнберзького й Токійського трибуналів це довели [8, c. 146]. Зокрема, вони призвели до того, що людина стала суб'єктом міжнародного права та отримала безпрецедентну можливість звертатись до міжнародних органів за захистом своїх прав. Г. Христова вважає, що ці 
процеси призвели до наступних безповоротних зрушень у розвитку ідеї прав людини:

1) держави, які ратифікували міжнародні договори у сфері прав людини, зобов'язались поважати права людини не стільки перед іншими державами, скільки перед особами, які перебувають під їхньою юрисдикцією, тобто перед громадянами, особами 3 громадянством інших держав, особами без громадянства, особами, які шукають притулку, мігрантами;

2) виконання державами зобов'язань у сфері прав людини в межах національного правопорядку може бути оцінено на національному та міжнародному рівнях уповноваженими судовими (чи квазі-судовими) установами, що тягне за собою відповідальність держави за їх порушення;

3) за державами визнається широка свобода обирати способи, якими вони реалізовуватимуть свої зобов'язання держав, яка все одно має свої межі, що в термінології міжнародного права прав людини носить назву «свобода розсуду» («margin of appreciation») [17];

4) варто додати також, що нині доктрина прав людини стоїть на тому, що недержавні суб'єкти - національні та міжнародні неурядові організації, корінні народи та національні меншини; правозахисники; терористи; воєнізовані групи; автономні округи; інтернаціоналізовані території; транснаціональні корпорації; нарешті, самі індивіди - значно впливають на права людини інших, у рівній мірі, опікуючись та потураючи порушенням або порушуючи права людини. «Горизонтальна дія» прав людини як складова ідеї прав людини сьогодні передбачає, що кожна людина і кожна суспільна структура зобов'язані робити свій внесок у створення атмосфери, що сприяє здійсненню прав людини, i це зобов'язання $\epsilon$ універсальним і стосується всіх як державних, так i недержавні акторів (суб'єктів). [17, с. 50].

Пригадаємо, що ст. 28 Декларації вимагає від держав та міжнародного устрою повної реалізації прав людини. 
Що це може означати і які $\epsilon$ загрози цій повноцінній реалізації прав людини? Тут можна навести славнозвісне визначення Європейського суду з прав людини, зроблене ним у справі Airey v. Ireland (1979) про те, що права людини мають бути практичними та ефективними, а не теоретичними та ілюзорними (§ 24). Теоретичність та ілюзорність як протиставлення практичній та повноцінній реалізації прав людини, можна допустити, означає те, що для когось права людини, визнані на універсальному рівні, стають недоступними взагалі або їх реалізація $\epsilon$ неможливою у повній мірі. Т. Погґе вважає, що «надійна можливість отримання всіма людьми певних невід'ємних благ є змістом і метою офіційних декларацій з прав людини і власне прав людини» [14]. Сьогодні це твердження $\epsilon$ справжнім викликом для багатьох держав у світі: брак рівності та справедливості має місце у всіх регіонах світу.

\section{2. Ідея глобальної справедливості: відповідь на нові виклики}

Тепер уже безсумнівним стало те, що справа прав людини стала справою глобального характеру. Справді, дуже багато проблем, з якими люди стикаються сьогодні вимушена міграція, зміни клімату, нерівність, економічні коливання чи порушення прав людини - мають сильний міжнародний і часто навіть глобальний вимір. Процеси глобалізації впливають на права людини у великій мірі, i примітним $є$ те, що цей вплив має як негативний характер, так і позитивний. Це означає, що глобалізаційні процеси можуть породжувати численні виклики для прав людини, але водночас містять ряд переваг та інструментів, що $\epsilon$ більш дієвими для реагування на загрози правам людини різного рівня та виду. Глобалізація, яка здебільшого розуміється як світова економічна уніфікація, відкрила безпрецедентні можливості для соціального i економічного розвитку, але в той же час викликала серйозні проблеми, такі як широкомасштабні фінансові кризи, ізоляцію і нерівність як всередині суспільств так і 
між ними, все більше число людей у різних країнах і навіть цілі регіони залишаються на периферії глобальної економіки [6].

Сьогодні на рівні Організації Об'єднаних Націй визнається вплив на права людини процесів глобалізації, особливо глобальної економіки, наслідки якого часто носять уже не економічний характер, а зачіпають найцінніше, що заявлене Загальною декларацією прав людини - гідність людини. Загрози правам людини, які створені інтенсифікацією економічних відносин доповнились загрозами безпеки, коли, як пишуть дослідники, «після 11 вересня - замість кантівського проекту вічного миру, що передбачав республіканський уряд, федеративний лад, усесвітнє право на тлі загального страху та незахищеності першочерговими стають турбота про безпеку та виживання, бажання панувати та розподіляти, але також постає гостра потреба справедливості та рівності серед незахищених верств населення у цьому «релятивному, самогубному і розчарованому світі» $[14$, c. 8$]$.

Глобальна справедливість - це теорія у межах вчення про міжнародні відносини, що фокусується на важливості особистості на відміну від держави, громади чи культури. Ця теорія, по суті, виступає своєрідною відповіддю на те, як зробити сучасний світ справедливим, і нагадує, що об'єднуючою ідеєю цілком може бути людина. Теорія глобальної справедливості існує в рамках ширшої школи космополітизму, який $є$ «багаторівневою» теорією, що має політичний, правовий, культурний та економічний вимір. Правовий космополітизм головним чином стосується справедливості в світовому масштабі і дотримання прав людини; він $\epsilon$ своєрідним викликом «винятковим привілеям націй-держав діяти як верховний арбітр у питаннях, які стосуються того, що слід або не слід вважати порушенням прав людини на своїй території» [2]. Варто відзначити те (і це має важливе значення для розуміння теорії справедливості), що синонімічною назвою 
глобальної справедливості $\epsilon$ «глобальна етика», що акцентує увагу на таких дилемах справедливості, які вимагають ретельного дослідження та відповідного реагування на них, як: «війна 3 тероризмом», недобросовісні країни, використання дитячої праці, застосування тортур в умовах їх абсолютної заборони, обмеженість ресурсів, торгівля людьми, міграція, зміни клімату, глобальна торгівля, медичний туризм, глобальні пандемії, гуманітарна інтервенція та багато інших [32]. Саме фокус на моральній цінності особистості, що здебільшого притаманне теоріям справедливості, які традиційно обмежуються національними державами i містяться в царині політичної (а не міжнародної) теорії, став поштовхом до появи та розвитку теорії глобальної справедливості, яка прагне дослідити питання про те, як найкраще забезпечити справедливе життя для всіх людей на планеті Земля, незалежно від їх національності чи статусу [20].

Американський професор Фрейзер Н., виступаючи на всесвітньому конгресі 3 філософії права і соціальної філософії, присвяченому справедливості у сучасному світі апелює до поділу розвитку світу на вестфальский та поствестфальський. У традиційній кейнсіансько-вестфальській системі, яка розглядала сферою застосування справедливості лише державу в її кордонах, а суб'єктом відповідних громадян, усі явища, пов'язані з міжнародною діяльністю, залишалися ніби поза дією справедливості. Професор вважає, що це зумовило зосередження на так званих питаннях «про що» (наш курсив) справедливості, тобто про те, що вважається справедливим у стосунках між громадянами: формальна рівність перед законом, рівність можливостей, відкритий доступ до ресурсів, політична участь і т.д. Однак, як підкреслює автор, теорія справедливості, адекватна розв'язанню проблем в умовах глобалізуючого суспільства, має включати поряд 3 економічним виміром перерозподілу і культурним виміром визнання ще i політичний вимір представництва. 
Права людини в Україні та у зарубіжних країнах:

проблеми теорії та нормативно-правової регламентації

Останнє дозволяє поряд із питаннями «про що» обговорювати також питання «хто» і «як» (наш курсив) справедливості, тобто хто може висувати вимогу перерозподілу i визнання i як такі вимоги мають обговорюватися та вирішуватися. Це, на думку доповідача, означає парадигмальне зрушення в осмисленні справедливості, що ставить на місце кейсіанськовестфальської соціальної справедливості поствестфальську демократичну справедливість [11, с. 276].

У чому полягає справедливість у світовому масштабі? Справедливість як правова цінність $€$ багатоаспектним явищем. Як підкреслює С. Погребняк, завдячуючи роботі Дж. Ролза «Теорії справедливості» можна сьогодні проводити розрізнення між формальною, змістовною і процедурною справедливістю. Основна ідея формальної справедливості - до однакового слід ставитись однаково, що конкретизується у вимогах безсторонності та неупередженості. I тут формальна справедливість означає рівність перед законом, рівність перед судом, рівність прав, свобод і обов'язків людини і громадянина. Змістовна справедливість передбачає наявність певних принципів, які пояснюють, що ж конкретно належить кожному як учаснику суспільних відносин. Це має важливе значення у таких сферах як обмін, де справедливість важлива як еквівалентність (комутативна справедливість) та розподіл, коли кожна окрема людина $\epsilon$ причетною до спільного блага шляхом його справедливого розподілу (дистрибутивна справедливість). Процедурна справедливість можна визначити як чесне дотримання процедурних правил, що спрямовані на забезпечення справедливості результату тієї чи іншої дії незалежно від інших обставин [10]. Можливо припустити, що справедливість у цих трьох вимірах можна екстраполювати на глобальний масштаб у тій мірі, в якій справедливість виступає принципом організації людського співіснування, і сьогодні іiї вимоги досить виразно відображаються в основних постулатах, які покладені в основу глобальної справедливості. 
Аналіз матеріалів дозволяє зробити висновок про те, що глобальна справедливість більше фокусується на дистрибутивному аспекті принципу справедливості, особливо у контексті проблем бідності. Так, Т. Погґе послідовно відстоює думку про те, що наявний міжнародний інституційний порядок не справляється із задачею забезпечення справедливості, він акцентує увагу на тому, що у світі посилюється крайня бідність; міжнародна спільнота допускає прихід до влади корумпованих урядів в бідніших країнах, які отримують право продавати ресурси країни та розпоряджатися доходами від таких продажів, позичати кошти від імені країни і тим самим покладати на неї зобов'язання 3 обслуговування боргу, підписувати договори від імені країни і таким чином зв'язувати їі теперішнє та майбутнє населення, а також використовувати державні доходи для проведення політик внутрішніх репресій [29]. Проте, як демонструють інші дослідження проблем глобалізації та прав людини, що процесуальний зріз справедливості має важливе значення. Так, право людей на навколишнє середовище передбачає право мати доступ до повної інформації про потенційні наслідки небезпеки для навколишнього середовища, право брати участь у демократичних процедурах щодо формування кліматичної політики та права на скарги на існуючі умови [20].

Британський правник сучасності Д. Хелд систематизував основні вісім принципів, що $\epsilon$ формальним вираженням космополітичних цінностей і затверджують рівне значення кожної особистості в «моральній царині всього людства». Зазначені принципи і становлять, як вважає автор, основу космополітичного права, що доповнює національне й міжнародне право. Д. Хелд показує глобальну справедливість як спосіб представлення рівного морального становища всіх людей, їх домагання на рівну волю і форми правління, засновані на обговоренні і згоді [20]. Це такі принципи: 
1) рівні цінність і гідність;

2) активна дія;

3) персональні відповідальність і підзвітність;

4) згода;

5) колективне прийняття рішень з публічних питань за допомогою процедур голосування;

6) включеність і субсидіарність;

7) запобігання серйозній шкоді;

8) можливість підтримки.

Ці принципи, укладені майже 20 років тому, сьогодні зберігають свою актуальність, і міжнародні зусилля, спрямовані на їх дотримання, збагатили їх зміст та вибудували нові орієнтири. Варто визнати, що багато у чому ідея глобальної справедливості поглибилась концепцією сталого розвитку. Уперше поняття сталого розвитку було сформульовано у 1987 році у Звіті Комісії $\mathrm{OOH}$ під керівництвом Гро Харлем Брутланда, і ним позначався такий розвиток суспільства, який задовольняе потреби нинішніх поколінь і не ставить під загрозу можливості наступних поколінь задовольняти свої потреби» [21]. На той момент концепція сталого розвитку була заявлена як така, що здатна підтримувати економічний прогрес, забезпечуючи при цьому довгостроковий захист навколишнього середовища. Сьогодні 17 Цілей сталого розвитку (далі - ЦСР), затверджені світовим суспільством, передбачають 169 завдань, виконання яких передбачено у строк до 2030 року: боротьба з бідністю та голоду в усьому світі, 3 нерівністю всередині країн та між ними; захист права людини, захист природних ресурсів планети; створення умов для сталого, всеохоплюючого i безперервного економічного зростання, процвітання всього людства i гідної праці для всіх з урахуванням різних рівнів розвитку і спроможності країн [30]. Концепцію сталого розвитку світу називають своєрідною «формулою компромісу», адже ій передував інтенсивний тривалий міжнародний переговорний процес, зміст якої повинен бути 
актуальними та застосовним у майбутньому, а також набула сенсу «регуляторної ідеї» [27].

Соціальна справедливість, як підкреслюється в дослідженнях, є невід'ємною частиною концепції сталого розвитку. Більше того, вважається також, що сталий розвиток багато у чому виходить за межі ліберальних теорій справедливості, які не враховують таких позицій, як 1) прискорення екологічної взаємозалежності, 2) несправедливість у використанні ресурсів та 3) «розширення меж» («growth of limits»). I саме це створює конфлікт між справедливістю між та серед поколінь, а концепція сталого розвитку намагається на ці виклики реагувати, чого не може концепція справедливості, (наприклад, це робиться шляхом накладення мита на розвинені країни, що виходить за рамки ліберальних вимог) [26].

Інтерес дослідників глобальної справедливості дійсно значним чином прикутий до проблем навколишнього середовища та кліматичних проблем, адже боротьба зі змінами клімату потребує спільних зусиль, що передбачає потребу в глобальних угодах, що зможе визначити відповідальних суб'єктів, які несуть відповідальність за допомогу тим, хто зазнає непропорційно тяжких наслідків від змін клімату, що $є$ питанням дистрибутивної справедливості. Зміна клімату найбільш негативно впливає на тих, хто живе у менш розвинених країнах, які зробили найменший внесок у причини зміни клімату, і навпаки - ті, хто живе у розвинених країнах, які зробили найбільше викидів, зазнають менше негативних наслідків [20].

Скажімо, ЦСР 13 спрямована на боротьбу із змінами клімату та подолання його наслідків, передбачає такі інструменти реагування:

- створення відповідних політик та стратегій на національному рівні (13.2);

- створення передумов, зокрема, освітніх та інформаційних, для посилення можливостей людей та установ щодо пом'якшення гостроти та послаблення 
наслідків зміни клімату, адаптації до них і раннього попередження (13.3);

- «виконання взятих на себе зобов'язань розвиненими країнами, які є учасниками Рамкової конвенції Організації Об'єднаних Націй про зміну клімату, зобов'язання досягти мети щорічної мобілізації до 2020 року загальними зусиллями 100 млрд дол. США 3 усіх джерел для задоволення потреб країн, що розвиваються, в контексті прийняття конструктивних заходів щодо пом'якшення гостроти наслідків зміни клімату та забезпечення прозорості їх здійснення, a також забезпечити повномасштабне функціонування Зеленого кліматичного фонду шляхом його капіталізації в найкоротші можливі терміни» (13.a);

- зміцнення спроможностей людей у найменш розвинених країнах і малих острівних державах, що розвиваються, приділяючи, зокрема, підвищену увагу жінкам, молоді, а також місцевим і маргіналізованим громадам (13.b) [18].

Звичайно, «кліматичний» порядок денний - один із ряду напрямів, які $\epsilon$ однаково важливими та взаємопов'язаними між собою, виконання ключових завдань по яким сприятиме відповіді на ті виклики глобальної справедливості, які $\epsilon$ найбільш нагальними. Як видно, концепція сталого розвитку намагається ще більше акцентувати увагу не лише на справедливості всередині нині існуючого покоління (intragenerational justice) подолання бідності, голоду забезпечення рівності у сфері зайнятості, подолання гендерної нерівності, забезпечення повного доступу до правосуддя, але і справедливості щодо наступних поколінь (intergenerational justice) - раціональне використання природних ресурсів та пильна увага до проблем клімату.

Варте особливої уваги те, що Порядок денний сталого розвитку зосередив значну увагу на тому, що недержавні суб'єкти по всьому світу, а саме бізнес, транснаціональні компанії, несуть відповідальність у сфері прав людини. 
Хоча, справедливо відзначити, що ця ідея отримала своє втілення раніше у Глобальному договорі ООН - всесвітній ініціативі, заснованій у 2000 році, спрямованій на сприяння соціальній відповідальності бізнесу та підтримці вирішення підприємницькими колами проблем глобалізації та створення більш стабільної та всеохоплюючої економіки. Але нині ця ініціатива багато у чому сприяє досягненню ЦСР. На сьогоднішній день існує більше ніж 3800 компаній, що стали учасниками Глобального Договору, та 47 національних мереж Глобального Договору. Глобальний Договір відстоює принципи соціальної відповідальності бізнесу з особливою увагою, спрямованою на досягнення цілей ООН у 4 основних сферах, зокрема, прав людини; трудових відносин; навколишнього середовища та боротьби 3 корупцією. Десять принципів, вміщених у Глобальному договорі Організації Об’єднаних Націй походять із: Загальної декларації прав людини, Декларації Міжнародної організації праці про основні принципи та права на виробництві, Декларації Ріо про навколишнє середовище та розвиток, та Конвенції ООН проти корупції. Ці принципи проголошують наступне:

1) підприємства повинні підтримувати i поважати захист міжнародно проголошених прав людини та 2) постійно перевіряти, що вони не $\epsilon$ співучасниками порушень прав людини;

3) підприємства повинні підтримувати свободу асоціацій та ефективне визнання права на колективні переговори;

4) підприємства повинні дотримуватись абсолютної заборони всіх форм примусової праці 5) а також заборони використовувати дитячу працю;

6) підприємства повинні усувати дискримінацію щодо зайнятості та професії;

7) підприємства повинні підтримувати запобіжний підхід до екологічних проблем; 
8) підприємства повинні здійснювати ініціативи щодо сприяння більшій екологічній відповідальності і

9) заохочувати розвиток та розповсюдження екологічно чистих технологій;

10) підприємства повинні боротися проти корупції у всіх її формах, включаючи вимагання та хабарництво [22].

До речі, варто відзначити, що учасники Глобального Договору ООН сформулювали своє особливе звернення для керівництва бізнесом у відповідь на кризу, викликану пандемією вірусу COVID-2019 та нагадали про важливість дотримання прав людини у цей складний період. Зокрема, вони закликають забезпечувати доступ до засобів захисту від вірусної інфекції усім без дискримінації, відповідати гнучкістю робочих умов, зберігати за можливості заробітну платню, максимально можливою мірою забезпечити виконання контрактів, сприяти дистанційній роботі, забезпечувати гігієну та безпеку робочого місця.

Варто додати, що через 11 років після прийняття Глобального договору Радою ООН із прав людини у 2011 року було ухвалено ще один документ, присвячений бізнесу i правам людини - Керівні принципи ООН щодо бізнесу та прав людини, які грунтуються на визнанні не тільки зобов'язань держави щодо поваги, захисту та реалізації прав людини й фундаментальних свобод; але і ролі бізнес-структур як спеціалізованих органів суспільства, на які покладено виконання спеціальних функцій і до яких висувається вимога діяти відповідно до усіх застосовних законів і дотримуватися прав людини. При цьому невід'ємне значення мають передбачення в національному праві та корпоративних правилах відповідних й ефективних засобів правового захисту для усіх, хто зазнав порушень прав з боку бізнесу. Ці Керівні принципи застосовуються до всіх держав та до всіх бізнес-підприємств, як транснаціональних, так і інших, незалежно від їх розміру, сектора, місцезнаходження, форми власності та структури. У самому документі вказано, що вони 
сприяють посиленню стандартів і практик у сфері бізнесу i прав людини 3 тим, щоб окремі особи й громади, чиї інтереси зачіпаються, могли досягати вимірювальних результатів, і в цьому аспекті тлумачити їх як внесок у забезпечення соціально стійкої глобалізації.

\section{Висновки}

Незважаючи на те, що ст. 28 Загальної декларації прав людини не проголошує конкретного субстантивного права, вона має надзвичайно важливе смислоутворююче значення для Загальної декларації та для глобального правозахисного механізму. Формулювання цієї статті дало поштовх для постійного критичного осмислення існуючого глобального порядку. Фокус на людині як основній цінності та важливість розвитку міжнародних, зокрема економічних відносин, змусив наукову думку та світове товариство розмірковувати над тим, як відшукати консенсус між збереженням цінності прав людини та розвитком міжнародної кооперації. Теорія глобальної справедливості стала належною відповіддю на такий запит, а ст. 28 як нормативне існування глобальної справедливості виступає нагадуванням для всіх про те, що сьогодні повна реалізація прав людини неможлива без врахування національного та міжнародного контекстів. Права людини та їх повне й ефективне забезпечення продовжують залишатись мірилом міжнародних політик та ініціатив. Тільки ретельна обачність з урахуванням справедливості та ідеї прав людини зможе вибудовувати чи трансформувати міжнародні практики та норми, щоб забезпечувати довгостроковий ефект корисних та належних рішень.

\section{Список використаних джерел:}

1. Венская декларация и Программа действий, Принята на Всемирной конференции по правам человека 25 июня 1993 г. в Вене. URL: https://zakon.rada.gov.ua/laws/ show/995_504. 
Права людини в Україні та у зарубіжних країнах:

проблеми теорії та нормативно-правової регламентації

2. Гібернау M. Національна ідентичність vs космополітична ідентичність. Незалежний культурологічний часопис. URL: http://www.jimagazine.lviv.ua/2016/ Gibernau_Nacionalna_identychnist.htm.

3. Гороть Є.I. Великий англо-український словник. Вінниця : Нова кн. ; Харків : Ранок, 2011.

4. Декларація про принципи міжнародного права, що стосуються дружніх відносин і співробітництва між державами відповідно до Статуту Організації Об’єднаних Націй, прийнята резолюцією 2625 (XXV) Генеральної Асамблеї ООН від 24 жовтня 1970 року. URL: https://zakon.rada.gov.ua/laws/show/995_569.

5. Сендс Ф. Східно-Західна вулиця: повернення до Львова / Пер. з англ. Мигаль П. Вид-во Старого Лева. Львів, 2017.

6. Доповідь Генерального секретаря «Глобалізація та ії вплив на здійснення в повному обсязі всіх прав людини», 31 серпня 2000.

7. Задорожній О.В. Поняття та нормативні вимоги основних принципів міжнародного права. Актуальні проблеми держави і права. 2015. Вип. 75. С. 242-255.

8. Київець О.В. Загальні принципи права як джерело міжнародного права: природно-правовий та позитивістські підходи. Вісник Маріупольського державного університету. Сер. : Право. 2013. Вип. 5. С. 141-148.

9. Коллер П. Сфера значущості прав людини / Філософія прав людини. за редакції Ш. Госепата, Г. Ломанна ; Пер. 3 нім. О. Юдіна та Л. Доронічевої. Київ : Ніка-Центр, 2008. C. 15-32, 87-129.

10. Ломанн Г., Госепат Ш. Вступ. Загальна декларація прав людини - політичний вплив i потреба у філософському проясненні. Філософія прав людини / за редакції Ш. Госепата, Г. Ломанна ; пер. 3 нім. О. Юдіна та Л. Доронічевої. Київ : Ніка-Центр, 2008. С. 15-32.

11. Максимов С.I. Право і справедливість у глобальному суспільстві: XXII Всесвітній конгрес з філософії права i 
соціальної філософії. Вісник Академії правових наук України. Вісник Академії правових наук України. № 4(47). С. 276.

12. Погґе Т. Права людини як моральні вимоги до глобальних інституцій. Філософія прав людини / за редакції Ш. Госепата, Г. Ломанна ; пер. 3 нім. О. Юдіна та Л. Доронічевої. Київ : Ніка-Центр, 2008.

13. Погребняк С. Особливості втілення в праві різних аспектів справедливості. Вісник Академії правових наук України. № 1(52). Харків : Право, 2008. С. 31-42.

14. Філософія прав людини / за редакції Ш. Госепата, Г. Ломанна ; пер. $з$ нім. О. Юдіна та Л. Доронічевої. Київ : Ніка-Центр, 2008.

15. Світовий маніфест правового гуманізму. Загальна декларація прав людини як основа міжнародного та національного правозахисту : монографія / Рабінович П.М., Наконечна А.М., Добрянський С.П. та ін. Праці Львівської лабораторії прав людини і громадянина Науково-дослідного інституту державного будівнищтва та місцевого самоврядування Національної академії правових наук України. Львів : БФ «Медицина і право», 2018. Вип. 33. 180 с. (Сер. I. Дослідження та реферати).

16. Філософія права : підруч.для студ. юрид. вищ. навч. закл. / О.Г. Данильян, О.П. Дзьобань, C.I. Максимов та ін. ; За ред. д-ра філос. наук, проф. О.Г. Данильяна. Харків : Право, 2009.

17. Христова Г.О. Доктрина позитивних зобов'язань держави у сфері прав людини : дис. ... докт. юридичних наук : 12.00 .01 ; НЮУ ім. Ярослава Мдурого, Міністерство освіти і науки України, 2019. 492 с.

18. Ціль 13. Вжиття невідкладних заходів щодо боротьби зі зміною клімату та його наслідками / Цілі сталого розвитку. URL: http://sdg.org.ua/ua/pro-hlobalnitsili/climate-action\#глобальні-завдання.

19. Annual Activity Report 2019, presented to the Committee of Ministers and the Parliamentary Assembly / Commissioner for Human Rights of the Council of Europe, 
Dunja Mijatović (Strasbourg, 21 April 2020). URL: https://rm.coe.int/annual-activity-report-2019-by-dunjamijatovic-council-of-europe-commi/16809e2117

20. Dietzel A. Introducing Global Justice in International RelationsTheory. URL: https://www.e-ir.info/2018/01/02/ global-justice-in-international-relations-theory/

21. Emas R. "The Concept of Sustainable Development: Definition and Defining Principles", Brief for GSDR 2015, accessed August 20, 2019. URL: https://sustainabledevelopment.un.org/content/documents/5 839GSDR\%202015_SD_concept_definiton_rev.pdf.

22. Global Compact. United Nations. URL: https://www.unglobalcompact.org.

23. Globalisation. КОМПАС : Посібник з освіти в області прав людини за участі молоді. URL: https://www.coe.int/ uk/web/compass/globalisation\#7.

24. Held D. 'Law of States, Law of Peoples: Three Models of Sovereignty' in Legal Theory. 8. 2002. URL: http://www.lse.ac.uk/globalGovernance/publications/articles AndLectures/lawsOfStatesLawsOfPeoples.pdf.

25. Josh Curtis, Shane Darcy. The right to a social and international order for the realisation of human rights: article 28 of the universal declaration and international cooperation / in David Keane and Yvonne McDermott (eds.), The Challenge of Human Rights : Past, Present and Future, Edward Elgar Publishing, 2012. P. 8.

26. Langhelle, Oluf. "Sustainable Development and Social Justice: Expanding the Rawlsian Framework of Global Justice". Environmental Values 9, no. 3 (2000): 127-52. doi: $10.3197 / 096327100129342074$.

27. Michelsen, G. "Sustainable Development - Background and Context" in Sustainability Science: An Introduction. ed.Heinrichs, H., et al. (Dordrecht: Springer.; 2013).

28. Orsini Amandine. Lessons learnt from Coronavirus and global environmental challenges. OUPblog (April 15th 2020). URL: https://blog.oup.com/2020/04/lessons-learnt-fromcoronavirus-and-global-environmental-challenges/. 
Права людини в Україні та у зарубіжних країнах:

29. Pogge T. Poverty and Human Rights. URL: https://www2.ohchr.org/english/issues/poverty/expert/docs/ Thomas_Pogge_Summary.pdf.

30. Resolution adopted by the General Assembly on 25 September, 2015 Transforming our world: the 2030 Agenda for Sustainable Development. URL: https://www.un.org/en/ development/desa/population/migration/generalassembly/do cs/globalcompact/A_RES_70_1_E.pdf.

31. Understanding Human Rights: An Overview. by O.P. Dhiman. Kalpaz Publications, 2011. 392 p.

32. Widdows, H. (2011). What is global ethics? In Global Ethics: An Introduction (pp. 1-12). Acumen Publishing. doi:10.1017/UPO9781844652839.001. 